International Research Journal of Management, IT \& Social Sciences
Available online at https://sloap.org/journals/index.php/irjmis/
Vol. 8 No. 3, May 2021, pages: 315-328
ISSN: 2395-7492
https://doi.org/10.21744/irjmis.v8n3.1786

\title{
The Role of Customer Satisfaction in Mediating the Influence of Service Quality and Perceived Value on Brand Loyalty
}

Anak Agung Diah Tarama Devi ${ }^{a}$ Ni Nyoman Kerti Yasa ${ }^{\text {b }}$

Article history:

Submitted: 9 March 2021

Revised: 27 April 2021

Accepted: 18 May 2021

\section{Keywords:}

brand loyalty; customer satisfaction; perceived value; service quality;

\begin{abstract}
The study investigates how service quality and perceived value influence the brand loyalty of Lion Air customers in Denpasar City and how these relationships are mediated by customer satisfaction. The research was conducted in Denpasar, Bali. The sample size of 128 respondents was collected through a questionnaire and has been tested for its validity and reliability. The analysis technique used is the analysis of the Structural Equation Model (SEM) and using Smart PLS 3.0. The results showed that service quality, perceived value, and customer satisfaction had a positive and significant effect on the brand loyalty of Lion Air customers in Denpasar City. Another result is that customer satisfaction can partially mediate the relationship between service quality and perceived value with the brand loyalty of Lion Air customers in Denpasar City. This research is expected to be empirical evidence for future research and be able to enrich the development of marketing management science related to service quality, perceived value, customer satisfaction, and brand loyalty. The practical implication in this research is that Lion Air customer loyalty can be created when consumers feel that the quality of service provided by Lion Air meets their expectations, feels added value when using Lion Air, and feels right and satisfied when using Lion Air.
\end{abstract}

International research journal of management, IT and social sciences (C) 2021. This is an open access article under the CC BY-NC-ND license (https://creativecommons.org/licenses/by-nc-nd/4.0/).

\section{Corresponding author:}

Devi, A.A.D.T.

Faculty of Economics and Business, University of Udayana, Bali, Indonesia

Email address: ninyomankertiy@gmail.com

\footnotetext{
${ }^{a}$ Faculty of Economics and Business, University of Udayana, Bali, Indonesia
}

Faculty of Economics and Business, University of Udayana, Bali, Indonesia 


\section{Introduction}

Nowadays, individual's requirement for transportation facilities to support their activities is increasing, both daily activities that can be supported by using land transportation alone, as well as sea transportation or air transportation. Director-General of Strengthening for Research and Development, Ministry of Research, Technology and Higher Education, Muhammad Dimyati stated that Indonesia is a huge country consisting of numerous islands. Therefore, commercial aircraft are vital for inter-island connectivity in Indonesia, given Indonesia's geographical conditions (www.technology-indonesia.com).

Airline companies in Indonesia used to be very limited and offered relatively expensive prices to be reached by the public, especially the middle to lower class, even though Indonesians needed airplane accommodation if they were going to travel both between islands and between countries. Seeing this opportunity, low-cost airlines or Low-Cost Carriers began to appear. The addition of low-cost carriers (LCC) in Indonesia such as Citilink, Air Asia, and Lion Air offers the opportunity to fly at a more economical price. Lion Air is one of the LCC airlines which controls the market share, especially for domestic flights. Lion Air is an Indonesian airline that uses a price leadership strategy, which according to Porter (2008), price leadership emphasizes the production of standardized products at very low unit costs for price-sensitive consumers. Lion Air can offer flight ticket prices that are relatively lower than its competitors with a price leadership strategy, they carry the slogan, We Make People Fly.

LCC airline services over the past few years are increasingly on the market. However, there are not a few LCC airlines that have not provided good quality of service, cabin, and maximum flight experience so that many consumers feel dissatisfied and disadvantaged. This is proven through customer reviews on the Skytrax website. Skytrax is a British consulting company that researches airlines. Skytrax assigns Lion Air to the category 2 - Star Airline Rating, which is a rating given to airlines with low service quality and generally below average quality in various aspects of the assessment. Category 2 - Star Airline Rating indicates that product, staff, and cabin service services are lacking or inconsistent. The overall user rating is 4 out of 10 with a total of 176 reviews. When viewed as a whole, the majority of reviews for Lion Air are bad reviews in terms of crew service, cabin comfort, cabin cleanliness, and delay time. The reviewers stated that Lion Air was an airplane that was not recommended as the customer's choice. (https://www.worldairlineawards.com)

The number of bad reviews causes customer loyalty to be reduced to Lion Air so that consumers can switch to other LCC airlines, even though brand loyalty is very important for the company. A large number of low-cost carriers in Indonesia has made competition in the aviation industry even tighter. If Lion Air only offers low prices and ignores service quality and does not provide added value in the eyes of consumers, dissatisfied customers have the potential to switch to another airline.

One factor that can affect customer loyalty is service quality. Service quality is a dynamic condition related to products, services, people, processes, and the environment that meet or exceed expectations. Service quality has a quality measurement that plays an important role in maintaining the sustainability of the industry, therefore quality measurement can be carried out in the manufacturing and service industries. Good quality service will increase the level of customer loyalty. A loyal person also sees the quality of service provided according to whether or not the service provided by the service provider, so that customers are not disappointed with the quality of service provided, it must be much better than the quality expected by the customer (Tiong, 2018). Service quality and attention to customers are an important part of the corporate culture which is reflected in the company's vision, mission, and values so that the company can implement superior service to customers and always measures the level of customer satisfaction and makes customers loyal to the company. The importance of awareness in providing superior service quality to create satisfaction and foster customer loyalty and accomplish objectives to survive in the competitive world of business (Kuntari et al., 2016; Hapsari et al., 2016).

Consumers will also become loyal to a brand if consumers feel that using a brand will provide more value. Perceived value is described as a comparison between the costs (time, money, and energy) provided and the benefits received by the customer (Hapsari et al., 2016; Ha \& Jang, 2010). Perceived value is a consumer assessment that is carried out by comparing the benefits/benefits to be received and sacrifice issued for a product (Ariyanti \& Sri, 2014; Oh, 1999). Chen (2015) argues that the factors that drive customer loyalty are better captured from the consumer's perspective. Furthermore, it shows that the perceived value by customers has a significant influence on customer loyalty, and competition among service providers plays an intermediary role in the relationship between value and loyalty. According to Yang \& Peterson (2004), customer value is a ratio of the benefits received by the customer with a sacrifice, and risk to get the products (goods and services) offered by the company. When the perceived value of the ratio perceived by customers for some economic sacrifices with the products offered by the company is not meeting 
customer expectations, it will lead to a dissatisfied attitude. Conversely, if it equals or exceeds customer expectations, the customer will feel satisfied. Perceived value is understood as a construction configured by two parts, one of the benefits received (economic, social, and relationship) and one of the sacrifices made (price, time, effort, risk, and convenience) by the customer. The perceived value is only a trade-off between quality and price (Prameka et al., 2016). Value has a strong bond with perception because the benefits received and the costs sacrificed will influence the forming of perceived value (Adnyani \& Sukaatmadja, 2019; Cronin Jr et al., 2000)

Good service quality, as well as the good perceived value by consumers, will later encourage consumers to be satisfied with a brand. Consumer satisfaction is the level of consumer feelings after comparing with expectations. Consumers who are satisfied with the value provided by a product or service are very likely to become loyal customers. Consumer satisfaction is also related to the encouragement of society's demands for the increasing quality of service today (Lumbantobing \& Priansa, 2018). Today, more companies believe that the key to winning the competition is to provide value and satisfaction to customers through the delivery of high-quality products and services at competitive prices (Solimun \& Fernandez, 2018).

Customer satisfaction has played a big role in market share as well as incorporate investment. Several theories explain how customer satisfaction is related to customer needs, where the customer will be satisfied once he is satisfied with the product offered to them. Many times customers have expectations for a given product. After purchasing a product, a customer will expect the new product to live up to his expectations. In a situation where the expectations for the product are not met, the customer will feel dissatisfied (Joudeh \& Dandis, 2018; Udo et al., 2010). Customer satisfaction as a process is a comparative assessment between the services provided and the previous expectations that consumers have. The result is the final stage of satisfaction that comes from the experience while using the brand (Rahim, 2016; Sari \& Giantari, 2020).

When customers see a better product or service value, get a higher value, and feel satisfaction, they then form an intention to repurchase or become loyal. In this way, the consumer shows a commitment to one brand. Brand loyalty can be measured through positive word of mouth, customer satisfaction, brand trust, price sensitivity. Loyalty to certain consumer brands will remain unchanged if the brand is available forever (Rizwan et al., 2013). Today's customers have a greater understanding of brands and they will repurchase a certain product category if they feel that the product has the right characteristics, quality of service, and the right price. In addition, they do not move to other companies to purchase products. Likewise, if different brands are available at lower prices that are of higher quality, consumers will remain loyal to their particular brands (Ahmed et al., 2014). The importance of consumer loyalty today makes all companies that produce goods and services always trying to make consumers loyal to them (Ermayanti et al., 2015).

Apart from some of the studies that have been described, some studies are different from the results of previous studies such as research conducted by Chinomona et al. (2014) found that perceived value does not have a positive and significant effect on loyalty. On the other hand, research conducted by Narotama (2019) found that service quality does not affect customer loyalty to a brand. Maisya et al. (2019) found that in their research consumers did not pay attention to the service quality of a company, so it was found that service quality did not affect brand loyalty.

Because of the research gap on the effect of service quality and perceived value on customer loyalty, a solution is needed in the form of a mediating variable between service quality and perceived value on customer loyalty. The suitable mediation variable is customer satisfaction. Customer satisfaction is an important factor in determining customer loyalty. Customers who are satisfied with a brand will tend to be loyal to that brand and do not move to another brand. Customer satisfaction is a strong predictor of influencing customer loyalty (Leninkumar, 2016; Minh \& Huu, 2016; El Adly, 2018). The use of mediation is supported by research by Joudeh \& Dandis (2018); Yacoba et al. (2016); Fatima et al. (2018); and Solimun \& Fernandes (2018) found that the satisfaction variable acts as a mediator between service quality and loyalty. As well as research conducted by Hapsari et al. (2016); Ashraf et al. 2018; Keshavarz \& Jamshidi, 2018); Atmaja \& Yasa (2020), who found that consumer satisfaction can mediate perceived value towards brand loyalty. Based on the background of the problem and the existence of a research gap, it is necessary to further investigate the role of consumer satisfaction in mediating the effect of service quality and perceived value on brand loyalty of Lion Air consumers in Denpasar City.

\section{Literature review}

\section{Service quality}

Parasuraman et al. (1988) define service quality as a comparison between the service that consumers perceive and the service that consumers expect. If the service received or felt is as expected, it means that the service quality is good

Devi, A. A. D. T., \& Yasa, N. N. K. (2021). The role of customer satisfaction in mediating the influence of service quality and perceived value on brand loyalty. International Research Journal of Management, IT and Social 
and satisfying, but if the service received exceeds consumer expectations, then the service quality is perceived to be very good and quality. Conversely, if the service received is lower than expected, then the service quality is perceived to be bad. According to Hapsari et al. (2017), after customers receive superior service quality from service providers, their perception of the brand increases, and they usually consider repurchasing the service and recommending it to others.

\section{Perceived value}

Perceived value is a construct configured by two parts, one of the benefits received (economic, social, and relationship) and one of the sacrifices made (price, time, energy, risk, and convenience) by the customer. This study will focus on the perceived value in a service context. The perceived value is a trade-off between quality and price (Prameka et al., 2016). Most of the definitions of perceived value describe value as a perception of what customers have received and what they have provided which is based on the customer's overall evaluation of store utility, products, and brand image (Nikhasemi et al., 2016, Yasa et al., 2020). For customers, to subscribe to a service continuously, they must feel some value in the product or service and with the delivery process and the image of the service provider or customer to feel the value, the benefits of enjoying the product or service, for example, the service provided must be more worth the price offered. In other words, the price must be worth the services offered (Omoregie, 2019; Kasiri et al. 2017).

\section{Customer satisfaction}

Customer satisfaction has played a big role in market share as well as incorporate investment. Research in the field has proposed several definitions of customer satisfaction. Many definitions focus on disconfirming all expectations. Several theories explain how customer satisfaction relates to customer needs, where a customer will be satisfied after he or she is satisfied with the product offered to them. Customer satisfaction can be defined as an individual's perception of either dissatisfaction or pleasure by comparing the perceived performance of a product concerning one's expectations (Leong et al., 2015). In a situation where the expectations for the product are not met, the customer will feel dissatisfied (Joudeh \& Dandis, 2018; Melastri \& Giantari, 2019). In a decision process, consumers will not stop at the consumption process. Consumers will carry out an evaluation process of their consumption. This is what is called a post-purchase or post-consumption alternative evaluation. The result of the post-consumption evaluation process is satisfaction or dissatisfaction with the consumption of a product or brand that has been done.

\section{Brand loyalty}

According to Tjiptono et al. (2012) say that customer loyalty is customer commitment to a brand, store, or supplier, based on a positive attitude and is reflected in consistent repeat purchases. One example of a positive attitude given by loyal customers includes repurchasing, trying to find products from one company even though they are far away, and also no longer considering other brands to buy other than those that are frequently purchased. Customer loyalty is a customer's intention to subscribe and recommend services to others and remain loyal to the organization (Hapsari et al., 2017; Permatasari \& Yasa, 2020). In today's highly competitive business environment, customer loyalty is touted as the best approach to differentiate the business from competitors (Joudeh \& Dandis, 2018)

\section{Materials and Methods}

The research design is an associative quantitative research that discusses the relationship between service quality variables, perceived value, customer satisfaction, and customer loyalty. The sampling technique used is the Non Probability Sampling technique with the purposive sampling method. The sample in this study is 128 respondents. Data were collected through a questionnaire with measurements using a 5-point Likert scale. This research variable construct adapts and modifies indicators from research conducted by Jiang \& Zhang (2016), Hapsari et al. (2017), Joudeh \& Dandis (2018), Omoregie (2019), Nikhasemi et al. (2016), and Leong et al. (2015). Responses of a sample of 128 have been tested using PLS-SEM modeling approach.

The conceptual framework in this study is as follows: 


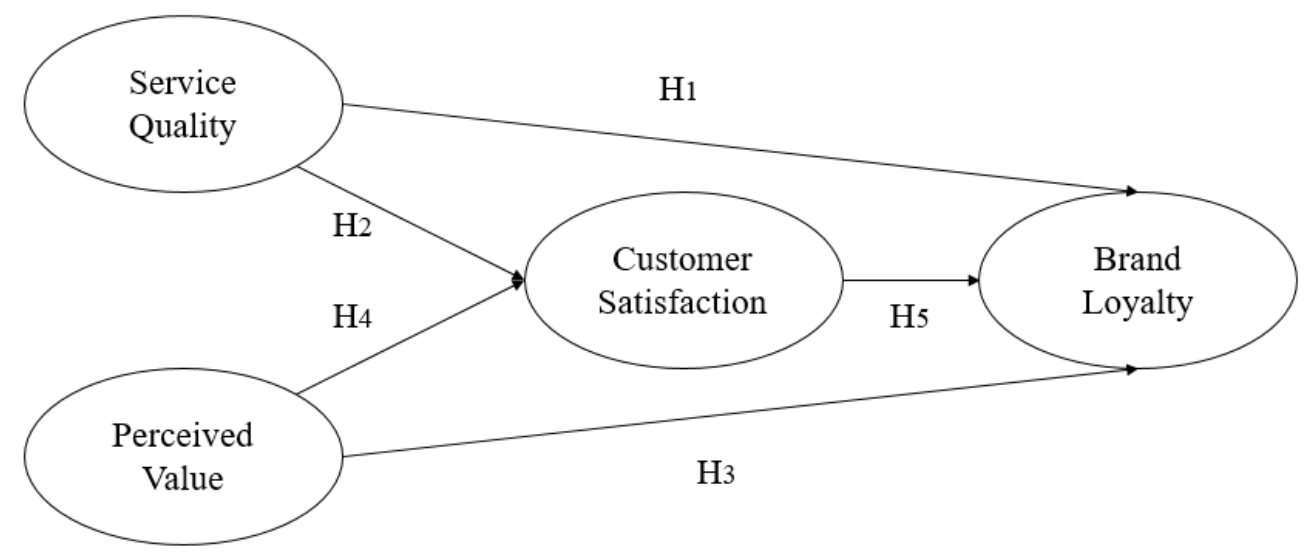

Figure 1. Research Conceptual Framework

Effect of service quality on brand loyalty

Research conducted by Leninkumar (2016) found that service quality has a significant positive effect on customer loyalty. This is in line with the research of Omoregie et al. (2019) who found that service quality has a positive and significant effect on customer loyalty. Research conducted by Chen \& Liu (2017) and Ofori et al. (2018) found the same thing, service quality has a positive and significant effect on customer loyalty. Based on the research results that have been described, the following hypothesis can be formulated:

H1: Service quality has a positive and significant effect on brand loyalty

Effect of service quality on customer satisfaction

Research conducted by Sari \& Lestari (2019) found that service quality was proven to have a positive and significant effect on customer satisfaction. This study is in line with research conducted by Saleem \& Raja (2014), Khan \& Fasih (2014), and Rahim (2016) who found that service quality has a positive and significant effect on satisfaction. Based on the research results that have been described, the following hypothesis can be formulated:

$\mathrm{H} 2$ : Service quality has a positive and significant effect on customer satisfaction

The effect of perceived value on brand loyalty

Strong values that can be maximized by brands can create consumer loyalty, found in research conducted by Ramadhan \& Siagian (2019) and Kusumawati \& Rahayu (2019) which found that perceived value has a positive and significant effect on customer loyalty. This is in line with the research conducted by Nikhashemi et al. (2016) and Amelia \& Keni (2019) who found that perceived value has a positive and significant effect on brand loyalty.

H3: Perceived value has a positive and significant effect on brand loyalty

The effect of perceived value on customer satisfaction

Perceived value describes a consumer's opinion or mental assessment of the value of a product or service provided to them. Research conducted by Demirgunes (2015) found that perceived value has a positive and significant effect on customer satisfaction. This is in line with the research of Prameka et al. (2016), Rasoolimanesh et al. (2016) and Iskandar et al. (2015) who also found that perceived value has a positive and significant effect on customer satisfaction. Based on the research results that have been described, the following hypothesis can be formulated:

H4: Perceived value has a positive and significant effect on customer satisfaction

Devi, A. A. D. T., \& Yasa, N. N. K. (2021). The role of customer satisfaction in mediating the influence of service quality and perceived value on brand loyalty. International Research Journal of Management, IT and Social 
The effect of customer satisfaction on brand loyalty

Customers can be considered satisfied if the purchase made by consumers for a product given by the company exceeds their expectations. Research conducted by Leong et al. (2015), Prayoga et al. (2015), Saraswita \& Yasa (2017), Famiyeh (2018), Budiarta \& Fachira (2017), Pratiwi et al. (2019), Atmaja \& Yasa (2020), Diputra \& Yasa (2021), found a positive and significant influence between consumer satisfaction on brand loyalty. Based on the research results that have been described, the following hypothesis can be formulated:

H5: Satisfaction has a positive and significant effect on brand loyalty

The role of satisfaction mediates service quality on brand loyalty

The indirect effect of consumer satisfaction in mediating service quality on brand loyalty is supported by research by Joudeh \& Dandis (2018) and research conducted by Yacoba et al. (2016) found that the satisfaction variable acts as a mediator between service quality and loyalty. As well as research conducted by Fatima et al. (2018) and Solimun \& Fernandez (2018) found that service quality is positively related to loyalty mediated through satisfaction. Based on the research results that have been described, the following hypothesis can be formulated:

H6: Customer satisfaction can mediate the effect of service quality on brand loyalty

The role of customer satisfaction mediates perceived value of brand loyalty

The indirect effect of consumer satisfaction in mediating perceived value on loyalty is supported by research by Hapsari et al. (2017); Ashraf et al. (2018), and research conducted by Keshavarz \& Jamshidi (2018) which found that consumer satisfaction is able to mediate perceived value of brand loyalty. Research conducted by Wantara (2018) also found that perceived value does not directly affect loyalty, but through satisfaction as a mediating variable. Based on the research results that have been described, the following hypothesis can be formulated:

H7: Consumer satisfaction can mediate the effect of perceived value on brand loyalty

\section{Results and Discussions}

Data analysis

\section{Respondent characteristics}

The number of respondents is 128 peoples, consisting of 46 men and 82 women. The age of the respondents in this study was in the age range $\leq 20$ years $-\geq 40$ years, with details of $\leq 20$ years amounting to 21 people, 21-30 years old totaling 64 people, $30-40$ years totaling 27 people, and $\geq 40$ years totaling 16 people. Respondents with the latest education at the high school level/equivalent are 38 people, 68 undergraduate and postgraduate students are 13 people, and others are 9 people.

Instrument test results

Validity and reliability test

A research instrument is said to be valid if the value of the correlation coefficient is equal to or greater than 0.30. All variable instruments in this study have a correlation coefficient above 0.30 , which means they have met the validity requirements of the instrument. A variable is said to be reliable if it has a Cronbach's Alpha $(\alpha)$ value above 0.70 . The sample used to test the reliability of the instrument was 30 respondents. All variable instruments in this study had a Cronbach's Alpha $(\alpha)$ value above 0.70 . This means that all instruments in this study are reliable

\subsection{Research Findings}

Evaluation of measurement model or outer model convergent validity 
Evaluation of measurement models based on outer loading for reflective indicators is considered valid if it has a loading value above 0.70 and or t-statistic value above 1.96. Table 1 shows that all indicators have an outer loading value of more than 0.7 , which can be concluded that the model in this study has fulfilled convergent validity.

Table 1

Results of convergent validity test

\begin{tabular}{llll}
\hline & Outer Loading & P value & Remark \\
\hline X1.1<- Service Quality & 0.828 & 0,000 & Valid \\
\hline X1.2 - Service Quality & 0.735 & 0,000 & Valid \\
\hline X1.3 <- Service Quality & 0.755 & 0,000 & Valid \\
\hline X1.4<- Service Quality & 0.813 & 0,000 & Valid \\
\hline X1.5<- Service Quality & 0.838 & 0,000 & Valid \\
\hline X1.6<- Service Quality & 0.863 & 0,000 & Valid \\
\hline X2.1<- Perceived Value & 0.896 & 0,000 & Valid \\
\hline X2.2<- Perceived Value & 0.802 & 0,000 & Valid \\
\hline X2.3<- Perceived Value & 0.821 & 0,000 & Valid \\
\hline X2.4<- Perceived Value & 0.818 & 0,000 & Valid \\
\hline M1.1<- Customer Satisfaction & 0.865 & 0,000 & Valid \\
\hline M1.2<- Customer Satisfaction & 0.867 & 0,000 & Valid \\
\hline M1.3<- Customer Satisfaction & 0.910 & 0,000 & Valid \\
\hline M1.4<- Customer Satisfaction & 0.852 & 0,000 & Valid \\
\hline Y1.1<- Brand Loyalty & 0.828 & 0,000 & Valid \\
\hline Y1.2<- Brand Loyalty & 0.735 & 0,000 & Valid \\
\hline Y1.3<- Brand Loyalty & 0.755 & 0,000 & Valid \\
\hline Y1.4<- Brand Loyalty & 0.813 & 0,000 & Valid \\
\hline
\end{tabular}

Source: Primary data processed, 2021

\section{Discriminant validity}

Table 2 shows that all construct variables have relatively good discriminant validity because all construct variables have an average variance extracted (AVE) value greater than 0.50 and Cronbach Alpha value exceeding 0.60.

Table 2

Results of discriminant validity test

\begin{tabular}{llllll}
\hline $\begin{array}{l}\text { Research } \\
\text { Variables }\end{array}$ & AVE & $\begin{array}{l}\text { Customer } \\
\text { Satisfaction } \\
(\mathrm{M})\end{array}$ & $\begin{array}{l}\text { Service } \\
\text { Quality } \\
(\mathrm{X} 1)\end{array}$ & $\begin{array}{l}\text { Loyalty } \\
(\mathrm{Y})\end{array}$ & $\begin{array}{l}\text { Perceived } \\
\text { Value (X2) }\end{array}$ \\
\hline Satisfaction (M) & 0.761 & 1.000 & 0.794 & 0.756 & 0.790 \\
\hline $\begin{array}{l}\text { Service Quality } \\
(\mathrm{X} 1)\end{array}$ & 0.651 & 0.794 & 1.000 & 0.757 & 0.760 \\
\hline Loyalty (Y) & 0.763 & 0.756 & 0.757 & 1.000 & 0.780 \\
\hline $\begin{array}{l}\text { Perceived Value } \\
(\mathrm{X} 2)\end{array}$ & 0.697 & 0.790 & 0.760 & 0.780 & 1.000 \\
\hline
\end{tabular}

\section{Composite reliability}

The construct reliability of the measurement model with reflective indicators can be measured by looking at the composite reliability value and reinforced by Cronbach's alpha value. The value of composite reliability and Cronbach's alpha is good if it has a value of > 0.60 (Ghozali, 2014). The following are the results of the instrument reliability research presented in Table 3.

Devi, A. A. D. T., \& Yasa, N. N. K. (2021). The role of customer satisfaction in mediating the influence of service quality and perceived value on brand loyalty. International Research Journal of Management, IT and Social 
Table 3

Results of composite reliability test

\begin{tabular}{lllll}
\hline No. & Variable & $\begin{array}{l}\text { Cronbach's } \\
\text { Alpha }\end{array}$ & $\begin{array}{l}\text { Composite } \\
\text { Reliability }\end{array}$ & Remark \\
\hline 1 & Service Quality & 0.892 & 0.918 & Reliable \\
\hline 2 & Perceived Value & 0.855 & 0.902 & Reliable \\
\hline 3 & Customer Satisfaction & 0.896 & 0.927 & Reliable \\
\hline 4 & Customer Loyalty & 0.897 & 0.928 & Reliable \\
\hline
\end{tabular}

\section{Evaluation of the structural model or inner model}

Evaluation of the structural model or inner model is carried out to ensure that the structural model built is robust and accurate. Testing can be done by calculating the value of $\mathrm{R}$ square and predictive relevance (Q2).

Table 4

$R$-square

\begin{tabular}{ll}
\hline Construct & $R$-square \\
\hline Customer Loyalty & 0,713 \\
\hline Brand Loyalty & 0,686 \\
\hline
\end{tabular}

Source: primary data processed, 2021

In Table 4, it can be seen that the $\mathrm{R}$-square value of the satisfaction variable is $71.3 \%$. The variability of the satisfaction construct is explained by the variable service quality and perceived value. Likewise, with the loyalty variable with an $\mathrm{R}$-square value of $68.6 \%$, the loyalty variable is influenced by service quality, perceived value and satisfaction. To measure how well the observed value is generated by the model and also its parameter estimates, it is necessary to calculate the Q-square $(\mathrm{Q} 2)$ as follows:

$$
\begin{aligned}
Q^{2}=1- & \left(1-R 1^{2}\right)\left(1-R 2^{2}\right) \\
& =1-\left(1-0,713^{2}\right)\left(1-0,686^{2}\right) \\
& =1-(0,4916)(0,5294) \\
& =1-0,260 \\
& =0,74
\end{aligned}
$$

From the results of the above calculations, it can be concluded that the model has a value $>0$, which is equal to 0.74 or $74 \%$. This shows that the model is good because it has a relevant predictive value, which is $74 \%$. It can be concluded that the loyalty variable is explained by the variables of service quality, perceived value, and satisfaction by $74 \%$, while the remaining $26 \%$ is explained by other variables outside the model. 


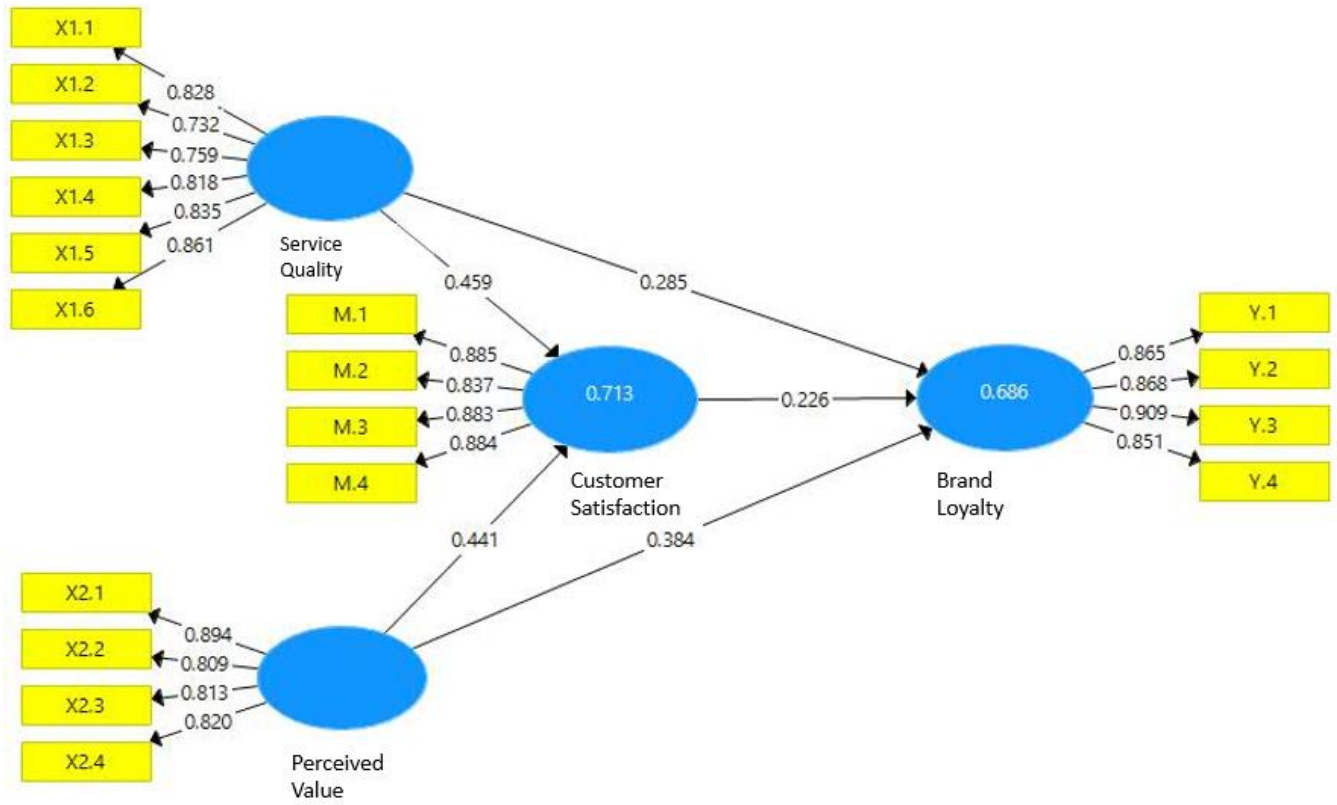

Figure 2. Structural research model

Testing the direct, indirect, and total effect between variables

The mediation effect assessment criteria are based on the VAF value. If the VAF value is $>80 \%$, the mediation variable is full mediation, if $\leq 20 \% \mathrm{VAF} \leq 80 \%$, the mediation variable is partial mediation and if $<20 \%$, the mediation variable is not a mediator. The results of the indirect effect test can be presented in Table 5 as follows.

Table 5

Indirect effect and total variable effect and the calculation of the VAF value

\begin{tabular}{|c|c|c|c|}
\hline \multirow{2}{*}{ Variable } & \multicolumn{3}{|c|}{ Indirect Effect } \\
\hline & Coefficient & t statistics & $\mathrm{P}$ values \\
\hline Service Quality -> Brand Loyalty & 0,104 & 2,385 & 0,017 \\
\hline \multirow[t]{2}{*}{ Variable } & Total Effect & & \\
\hline & 0,389 & 4,780 & 0,000 \\
\hline $\begin{array}{l}\text { VAF -> Indirect effect / Total effect ( } \\
0,114 / 0,414)\end{array}$ & 0,267 & & \\
\hline \multirow{2}{*}{ Variable } & \multicolumn{3}{|c|}{ Indirect Effect } \\
\hline & Coefficient & t statistics & $\mathrm{P}$ values \\
\hline Perceived Value -> Brand Loyalty & 0,100 & 2,198 & 0,028 \\
\hline \multirow[t]{2}{*}{ Variable } & Total Effect & & \\
\hline & 0,484 & 5,871 & 0,000 \\
\hline $\begin{array}{l}\text { VAF -> Indirect effect / Total effect ( } \\
0,472 / 0,149)\end{array}$ & 0,207 & & \\
\hline
\end{tabular}

Table 5 shows that the coefficient value of the direct influence between the variables of service quality and brand loyalty is 0.283 . The addition of the satisfaction variable as a mediating variable has a different effect on the direct relationship between service quality and brand loyalty. The explanation of Table 5 shows that the VAF value obtained from the distribution of the coefficient of the indirect effect with the total effect is 0.267 . This means that the role of satisfaction as a mediating variable is 26.7 percent. The mediation value of 26.7 percent is in the range of 20 percent

Devi, A. A. D. T., \& Yasa, N. N. K. (2021). The role of customer satisfaction in mediating the influence of service quality and perceived value on brand loyalty. International Research Journal of Management, IT and Social Sciences, 8(3), 315-328. https://doi.org/10.21744/irjmis.v8n3.1786 
to 80 percent. It can be interpreted that these variables are classified as partial mediating variables. It can be concluded that the results in this study indicate that the satisfaction variable can partially mediate the relationship between service quality and brand loyalty.

Furthermore, Table 5 shows that the coefficient value of the direct influence between the value perception variable and brand loyalty is 0.384 . The addition of the satisfaction variable as a mediating variable has a different effect on the direct relationship between perceived convenience and repurchase intention. The explanation of Table 5 shows that the VAF value obtained from the distribution of the coefficient of the indirect effect with the total effect is 0.207 . This means that the role of satisfaction as a mediating variable is 20.7 percent. The mediation value of 20.7 percent is in the range of 20 percent to 80 percent.

It can be interpreted that these variables are classified as partial mediating variables. It can be concluded that the results in this study indicate that the satisfaction variable can partially mediate the relationship between perceived value and brand loyalty.

\subsection{Discussion}

\section{Effect of service quality on brand loyalty}

The results of the analysis show that service quality has a positive and significant effect on brand loyalty. This means that the better the quality of service provided by the Lion Air airline, the higher the loyalty or loyalty of consumers in using the Lion Air brand as their preferred airline. This research is in line with research conducted by Leninkumar (2016); Chen \& Liu (2017); Ofori et al. (2018) and Omoregie et al. (2019) who found that service quality has a positive and significant effect on brand loyalty.

\section{Effect of service quality on customer satisfaction}

The results of the analysis show that service quality has a positive and significant effect on customer satisfaction. This means that the better the quality of service that Lion Air can provide, and if it can exceed consumer expectations, of course, it will increase customer satisfaction. These results are in line with research conducted by Sari \& Lestari (2019); Saleem \& Raja (2014); Khan \& Fluent (2014); Sanjaya \& Yasa (2018); and Rahim (2016) who found that service quality has a positive and significant effect on customer satisfaction.

\section{The effect of perceived value on brand loyalty}

The results of the analysis show that perceived value has a positive and significant effect on brand loyalty. This means that the better the value felt by consumers after using Lion Air, the more loyalty will be. Great service quality, or has added value in the eyes of consumers certainly has effect on loyalty. Previous research that is in line with this research is research conducted by Ramadhan \& Siagian (2019); Kusumawati \& Rahayu (2019); Nikhashemi et al. (2016); and Amelia \& Keni (2019).

\section{The effect of perceived value on brand satisfaction}

The results of the analysis show that perceived value has a positive and significant effect on customer satisfaction. The relationship between perceived value and customer satisfaction is when customers expect to receive benefits that are greater than the cost of each purchase made. When there are additional benefits that can be felt by consumers, purchases become more valuable and satisfaction will increase. Previous research that is in line with this research is research conducted by Demirgunes (2015); Iskandar et al. (2015); Prameka et al. (2016); Rasoolimanesh et al. (2016).

\section{The effect of satisfaction on brand loyalty}

The results of the analysis show that customer satisfaction has a positive and significant effect on brand loyalty. This means that the higher customer satisfaction, the more loyalty will increase. These results indicate that the hypothesis is accepted, so there is a positive and significant relationship between the satisfaction variables and brand loyalty. The higher customer satisfaction after using Lion Air airline services, the higher the consumer's desire to be loyal or become loyal Lion Air customers. These results are in line with research conducted by Prayoga et al. (2015), Putra et al. (2018), 
Rasmiati \& Yasa (2019), Carolina \& Yasa (2019), and Natya et al. (2020), Diputra \& Yasa (2021). Customers become loyal to a brand when customers are satisfied with the service they used.

The role of customer satisfaction in mediating service quality on brand loyalty

The results of the analysis show that customer satisfaction is able to mediate the effect of service quality on brand loyalty. This research supports research conducted by Joudeh \& Dandis (2018); Yacoba et al. (2016); Fatima et al. (2018); and Solimun \& Fernandez (2018) found that service quality is positively related to loyalty that is mediated through satisfaction.

The role of consumer satisfaction in mediating value perceptions of brand loyalty

The results of the analysis show that customer satisfaction can mediate the effect of perceived value on brand loyalty. This research is in line with research conducted by Hapsari et al. (2017); Ashraf et al. (2018); Keshavarz \& Jamshidi (2018) who found that consumer satisfaction can mediate perceived value towards brand loyalty. Research conducted by Wantara (2018) also found that perceived value does not directly affect loyalty, but through satisfaction as a mediating variable.

\section{Implications, Limitations, and Future Research}

\section{Implications}

The results of this study provide additional contributions to the existing literature, especially those related to service quality, perceived value, customer satisfaction, and brand loyalty. This study does not only examine the direct relationship between service quality and perceived value on brand loyalty. However, it also tests the indirect effect, namely through the customer satisfaction variable. The results of this study are expected to have implications for the management of the Lion Air airline company as a material for consideration and evaluation of consumer loyalty and the factors that influence it such as service quality, perceived value, and customer satisfaction. The managerial implication of this research is that this research is expected to provide information to companies that must be able to maintain the quality of services provided, provide added value to consumers so that consumers feel satisfied and get positive benefits when using Lion Air and will become loyal consumers of Lion Air.

\section{Research limitations and future research directions}

The research scope is limited to Denpasar City, so the results cannot be generalized to other areas. This research was only conducted at a certain period or cross-sectional, while the environment is dynamic, so it is hoped that this research can be carried out again in the future. This study is limited to only examining brand loyalty which is caused by service quality, perceived value, and customer satisfaction so that it cannot examine the factors outside of these variables in more depth.

\section{Conflict of interest statement}

The authors declared that they have no competing interests.

\section{Statement of authorship}

The authors have a responsibility for the conception and design of the study. The authors have approved the final article.

\section{Acknowledgments}

We are grateful to two anonymous reviewers for their valuable comments on the earlier version of this paper.

\footnotetext{
Devi, A. A. D. T., \& Yasa, N. N. K. (2021). The role of customer satisfaction in mediating the influence of service quality and perceived value on brand loyalty. International Research Journal of Management, IT and Social Sciences, 8(3), 315-328. https://doi.org/10.21744/irjmis.v8n3.1786
} 


\section{References}

Adnyani, D. A. M. E. S., \& Sukaatmadja, I. P. G. (2019). Peran perceived risk dalam memediasi pengaruh perceived quality terhadap perceived value. E-Jurnal Manajemen, 8(12), 7072-7092.

Ahmed, Z., Rizwan, M., Ahmad, M., \& Haq, M. (2014). Effect of brand trust and customer satisfaction on brand loyalty in Bahawalpur. Journal of Sociological Research, 5(1), 306-326.

Amelia, F. (2019). Pengaruh Customer Perceived Value, Customer Satisfaction, Dan Product Innovation Terhadap Customer Loyalty (Studi Kasus Rebranding All New Sour Sally). Jurnal Manajemen Bisnis dan Kewirausahaan, 3(1).

Ariyanti, K. (2014). Pengaruh persepsi nilai dan persepsi resiko terhadap niat beli kosmetik organik. Jurnal Ilmu Manajemen (JIM), 2(4).

Ashraf, S., Ilyas, R., Imtiaz, M., \& Ahmad, S. (2018). Impact of service quality, corporate image and perceived value on brand loyalty with presence and absence of customer satisfaction: A study of four service sectors of Pakistan. International Journal of Academic Research in Business and Social Sciences, 8(2), 452-474.

Atmaja, G. K. K., \& Yasa, N. N. K. (2020). The Role of Customer Satisfaction in Mediating the Influence of Price Fairness and Service Quality on the Loyalty of Low Cost Carriers Customers in Indonesia. International Research Journal of Management, IT and Social Sciences, 7(5), 149-159.

Budiarta, S. I., \& Fachira, I. (2017). Customer loyalty: the effects of service loyalty and the mediating role of customer satisfaction study case: PT Sabda Alam hotel. Journal of Business and Management, 251.

Carolina, D., \& Yasa, N. N. K. (2019). The Effect of Customer Relationship Management on the Satisfaction to Build Customers' Loyalty (Study Case of Go-Jek's Transportation Service Users). Economic Research, 3(5), 9-20.

Chen, C. M., \& Liu, H. M. (2017). Exploring the impact of airlines service quality on customer loyalty: Evidence from Taiwan. International Journal of Business and Management, 12(5), 36-50.

Chen, S. C. (2015). Customer value and customer loyalty: Is competition a missing link?. Journal of retailing and consumer services, 22, 107-116. https://doi.org/10.1016/j.jretconser.2014.10.007

Chinomona, R., Masinge, G., \& Sandada, M. (2014). The influence of e-service quality on customer perceived value, customer satisfaction and loyalty in South Africa. Mediterranean Journal of Social Sciences, 5(9), 331.

Cronin Jr, J. J., Brady, M. K., \& Hult, G. T. M. (2000). Assessing the effects of quality, value, and customer satisfaction on consumer behavioral intentions in service environments. Journal of retailing, 76(2), 193-218. https://doi.org/10.1016/S0022-4359(00)00028-2

Demirgünescedil, B. K. (2015). Relative importance of perceived value, satisfaction and perceived risk on willingness to pay more. International Review of Management and Marketing, 5(4).

Diputra, I G.N.A.W. \& Yasa, Ni Nyoman Kerti. (2021). The Influence Of Product Quality, Brand Image, Brand Trust On Customer Satisfaction And Loyalty, American International Journal of Business Management, 4(1), 25-34.

El-Adly, M. I. (2019). Modelling the relationship between hotel perceived value, customer satisfaction, and customer loyalty. Journal of Retailing and Consumer Services, 50, 322-332. https://doi.org/10.1016/j.jretconser.2018.07.007

Ermayanti, Z., Apriliani, E., Nurhadi, H., \& Herlambang, T. (2015, October). Estimate and control position autonomous underwater vehicle based on determined trajectory using fuzzy Kalman filter method. In 2015 International Conference on Advanced Mechatronics, Intelligent Manufacture, and Industrial Automation (ICAMIMIA) (pp. 156-161). IEEE.

Famiyeh, S., Asante-Darko, D., \& Kwarteng, A. (2018). Service quality, customer satisfaction, and loyalty in the banking sector. International Journal of Quality \& Reliability Management.

Fatima, T., Malik, S. A., \& Shabbir, A. (2018). Hospital healthcare service quality, patient satisfaction and loyalty. International Journal of Quality \& Reliability Management.

Ghozali, I. (2014). SEM Metode Alternatif dengan menggunakan Partial Least Squares (PLS). Semarang: Badan Penerbit Universitas Diponegoro.

Ha, J., \& Jang, S. S. (2010). Effects of service quality and food quality: The moderating role of atmospherics in an ethnic restaurant segment. International journal of hospitality management, 29(3), 520-529. https://doi.org/10.1016/j.ijhm.2009.12.005

Hapsari, R., Clemes, M. D., \& Dean, D. (2017). The impact of service quality, customer engagement and selected marketing constructs on airline passenger loyalty. International Journal of Quality and Service Sciences.

Hapsari, R., Clemes, M., \& Dean, D. (2016). The mediating role of perceived value on the relationship between service quality and customer satisfaction: Evidence from Indonesian airline passengers. Procedia Economics and Finance, 35, 388-395. https://doi.org/10.1016/S2212-5671(16)00048-4 
Iskandar, D., Nurmalina, R., \& Riani, E. (2015). The effect of service, product quality, and perceived value on customer purchase intention and satisfaction. Indonesian Journal of Business and Entrepreneurship (IJBE), 1(2), 51-51.

Jiang, H., \& Zhang, Y. (2016). An investigation of service quality, customer satisfaction and loyalty in China's airline market. Journal of air transport management, 57, 80-88. https://doi.org/10.1016/j.jairtraman.2016.07.008

Joudeh, J. M., \& Dandis, A. (2018). Service quality, customer satisfaction and loyalty in an internet service providers. International Journal of Business and Management, 13(8), 108-120.

Kasiri, L. A., Cheng, K. T. G., Sambasivan, M., \& Sidin, S. M. (2017). Integration of standardization and customization: Impact on service quality, customer satisfaction, and loyalty. Journal of Retailing and Consumer Services, 35, 91-97. https://doi.org/10.1016/j.jretconser.2016.11.007

Keshavarz, Y., \& Jamshidi, D. (2018). Service quality evaluation and the mediating role of perceived value and customer satisfaction in customer loyalty. International Journal of Tourism Cities.

Khan, M. M., \& Fasih, M. (2014). Impact of service quality on customer satisfaction and customer loyalty: Evidence from banking sector. Pakistan Journal of Commerce and Social Sciences (PJCSS), 8(2), 331-354.

Kuntari, B.D. Kumadji, Srikandi, H.K. (2016). Pengaruh Kualitas Pelayanan Terhadap Kepuasan Dan Loyalitas Pelanggan (Survei Pada Pelanggan Bengkel PT Astra International Tbk - Daihatsu Malang). Jurnal Administrasi Bisnis (JAB), 36(1), 196-202.

Kusumawati, A \& Rahayu, K.S. (2019). The effect of experience quality on customer perceived value and customer satisfaction and its impact on customer loyalty. The TQM Journal, 32(6): 1525-1540.

Leninkumar, V. (2016). The effect of service quality on customer loyalty. European Journal of Business and Management, 8(33), 44-49.

Leong, L. Y., Hew, T. S., Lee, V. H., \& Ooi, K. B. (2015). An SEM-artificial-neural-network analysis of the relationships between SERVPERF, customer satisfaction and loyalty among low-cost and full-service airline. Expert systems with applications, 42(19), 6620-6634. https://doi.org/10.1016/j.eswa.2015.04.043

Lumbantobing, S. M., \& Priansa, D. J. (2018). Pengaruh Persepsi Nilai Terhadap Kepuasan Konsumen Pengguna Kereta Api. eProceedings of Applied Science, 4(3).

Maisya, K.L., Syah, T.Y.R., \& Anindita, R. (2019). Influence Of Service Quality And Customer Satisfaction On Customer Loyalty In Restaurants Of The Tangerang Area. RJOAS, 8(92):142-147.

Melastri, K., \& Giantari, I. G. A. K. (2019). Effect of Service Quality, Company Image, and Customer Satisfaction in Word of Mouth. International Research Journal of Management, IT and Social Sciences, 6(4), $127-134$.

Narotama, A. (2019). The Effect of Service Quality on Customer Loyalty with Brand Images and Customer Satisfaction as Mediation. Jurnal manajemen dan kewirausahaan, 7(1), 86-93.

Natya, Ayu, Rahanata, Gede Bayu, Yasa, Ni Nyoman Kerti. (2020). Building Customer Loyalty Through Customer Satisfaction that Influenced by Promotion, Trust and Perceived Ease of Use, American Journal of Humanities and Social Science Research, 4(11).

Ngo, V. M., \& Nguyen, H. H. (2016). The relationship between service quality, customer satisfaction and customer loyalty: An investigation in Vietnamese retail banking sector. Journal of Competitiveness.

Nikhashemi, S. R., Tarofder, A. K., Gaur, S. S., \& Haque, A. (2016). The effect of customers' perceived value of retail store on relationship between store attribute and customer brand loyalty: Some insights from Malaysia. Procedia Economics and Finance, 37, 432-438. https://doi.org/10.1016/S2212-5671(16)30148-4

Ofori, K. S., Boakye, K., \& Narteh, B. (2018). Factors influencing consumer loyalty towards $3 \mathrm{G}$ mobile data service providers: evidence from Ghana. Total Quality Management \& Business Excellence, 29(5-6), 580-598.

Oh, H. (1999). Service quality, customer satisfaction, and customer value: A holistic perspective. International Journal of Hospitality Management, 18(1), 67-82. https://doi.org/10.1016/S0278-4319(98)00047-4

Omoregie, O.K., John, A.A., Stanley C., George, O.A.A., \& Kwame S.O. (2019). Factors influencing consumer loyalty: evidence from the Ghanaian retail banking industry. International Journal of Bank Marketing, 1-24.

Parasuraman, A., Zeithaml, V. A., \& Berry, L. (1988). Servqual: A multiple-item scale for measuring consumer perceptions of service quality. 1988, 64(1), 12-40.

Peterson, R. (2004). Crafting information technology governance. Information systems management, $21(4)$, 7-22.

Porter, M. E. (2008). Competitive Advantage (Keunggulan Bersaing) Menciptakan dan Mempertahankan Kinerja Unggul. Alih Bahasa: Tim Penerbit. Jakarta: Karisma Publishing Group.

Prameka, A. S., Do, B. R., \& Rofiq, A. (2017). How brand trust is influenced by perceived value and service quality: mediated by hotel customer satisfaction. APMBA (Asia Pacific Management and Business Application), 5(2), 7388.

Devi, A. A. D. T., \& Yasa, N. N. K. (2021). The role of customer satisfaction in mediating the influence of service quality and perceived value on brand loyalty. International Research Journal of Management, IT and Social Sciences, 8(3), 315-328. https://doi.org/10.21744/irjmis.v8n3.1786 
Pratiwi, H., Rosmawati, P., \& Usman, O. (2019). Effect of price, promotion, brand trust, and customer satisfaction on customer loyalty in packaging products mineral water aqua. Promotion, Brand Trust, and Customer Satisfaction on Customer Loyalty in Packaging Products Mineral Water Aqua (January 8, 2019).

Prayoga, I. M. S., Yasa, N. N. K., \& Wardana, M. (2015). Relational Benefit, Kepuasan, Dan Loyalitas Pelanggan Pada Bengkel Pt Honda Dewata Motor. Jurnal Manajemen dan Kewirausahaan (Journal of Management and Entrepreneurship), 17(1), 11-20.

Putra, D. K., Rahyuda, K. Y. N. N. (2018). The Role Of Satisfaction And Trust In Mediating The Relationship Of Brand Experience And Loyalty (A Study On Consumers Of Hilo Brand Milk Product), International Journal of Economic, Commerce and Management (IJECM), 6 (1).

Rahim, A. G. (2016). Perceived service quality and customer loyalty: The mediating effect of passenger satisfaction in the Nigerian Airline Industry.

Ramadhan, L., \& Yolanda Masnita Siagian, M. M. Impact of Customer Perceived Value on Loyalty: In Context Crm. 7(3), 24-29.

Rasmiati, D. \& Yasa, N. N. K. (2018). The Effect Of Retail Service And Store Image On Customer Satisfaction And Loyalty In Nirmala Supermarket Jimbaran-Bali, European Journal of Business, Economics and Accountancy, 7 (3).

Rasoolimanesh, S. M., Dahalan, N., \& Jaafar, M. (2016). Tourists' perceived value and satisfaction in a communitybased homestay in the Lenggong Valley World Heritage Site. Journal of Hospitality and Tourism Management, 26, 72-81. https://doi.org/10.1016/j.jhtm.2016.01.005

Rizwan, M., Usman, A., Hussain, T., Shafiq, A., Rauf, S., \& Aian Ayaz, Q. U. (2013). The impact of the perceived quality, customer satisfaction, brand trust and contextual factors on brand loyalty. clear International Journal of Research in Commerce \& Management, 4(3).

Saleem, H., \& Raja, N. S. (2014). The impact of service quality on customer satisfaction, customer loyalty and brand image: Evidence from hotel industry of Pakistan. Middle-East Journal of Scientific Research, 19(5), 706-711.

Sanjaya, D. P. E., \& Yasa, N. N. (2018). The Effect of Service Quality on Customer Satisfaction, Positive Word of Mouth and Corporate Image. Journal of Business and Management, 20(7), 28-33.

Saraswita, P. I. \& Yasa, Ni Nyoman Kerti. (2017). The Effect of Perceived Justice on Customer Satisfaction and Loyalty at PT Bank BPD Bali, International Journal Multidiciplinary Education and Research, 2 (6), 20 -25.

Sari, A. A. R. P., \& Yasa, N. N. K. (2020). Kepercayaan pelanggan di antara hubungan citra perusahaan dan kewajaran harga dengan loyalitas pelanggan mapemall. com. Penerbit Lakeisha.

Sari, D. A. T., \& Giantari, I. G. A. K. (2020). Role of Consumer Satisfaction in Mediating Effect of Product Quality on Repurchase Intention. International Research Journal of Management, IT and Social Sciences, 7(1), 217-226.

Sari, M. R., \& Lestari, R. (2019). Pengaruh Persepsi Harga, Kualitas Pelayanan Dan Kualitas Produk Terhadap Kepuasan Dan Dampaknya Pada Minat Pembelian Ulang Konsumen Keretaapi Kelas Eksekutif Argo Parahyangan. Oikonomia: Jurnal Manajemen, 15(1).

Solimun, S., \& Fernandes, A. A. R. (2018). The mediation effect of customer satisfaction in the relationship between service quality, service orientation, and marketing mix strategy to customer loyalty. Journal of Management Development.

Tiong, P. (2018). Pengaruh kualitas pelayanan terhadap loyalitas pelanggan pt. primagum sejati di makassar. SEIKO: Journal of Management \& Business, 1(2), 176-203.

Tjiptono, F. (2012). Pemasaran Strategik. Andi Offset. Yogyakarta.

Udo, G. J., Bagchi, K. K., \& Kirs, P. J. (2010). An assessment of customers'e-service quality perception, satisfaction and intention. International Journal of Information Management, 30(6), 481-492. https://doi.org/10.1016/j.ijinfomgt.2010.03.005

Wantara, P. (2018). Effect of service quality and perceived value satisfaction and loyalty religious tourists visit Island Madura, Indonesia. International Journal of Social Science and Economics Invention, 2(04), 325-to.

Yacob, Y., Ali, J. K., Baptist, C. J., Nadzir, H. M., \& Morshidi, M. H. (2016). How far members' satisfaction mediated members' loyalty? Investigating credit cooperative in Sarawak Borneo. Procedia-Social and Behavioral Sciences, 224, 376-383. https://doi.org/10.1016/j.sbspro.2016.05.391

Yang, Z., \& Peterson, R. T. (2004). Customer perceived value, satisfaction, and loyalty: The role of switching costs. Psychology \& marketing, 21(10), 799-822.

Yasa, N. N. Kerti, P.L.D. Rahmayanti, I G. N. A.J. Widagda, I B. A. Dharmanegara (2020). Perceived Value On Adapting To Online Study: Indonesian Student Perspectives during the COVID-19 Pandemic Period, SSRG International Journal of Economics and Management Studies, 7 (8), 178-186. 